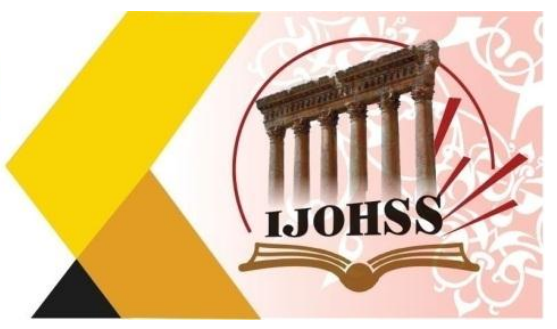

\title{
جائحة كورونا واثرها النفسي على معلمة رياض الاض الاطفال
}

\author{
م.م. دلال جاسم عبد الرضا \\ رياض الاطفال

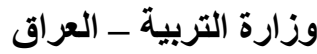

irag.201197@gmail.com البريد الاككتروني:

المدّ الاهتصام بالصحة النفسية في مثل هذه الفترات العصيبة أمرًا غاية في الأهمية، إذ يجب اتخاذ الإجراءات التهات

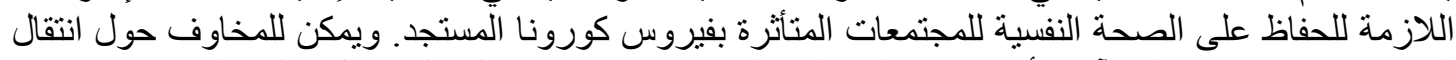

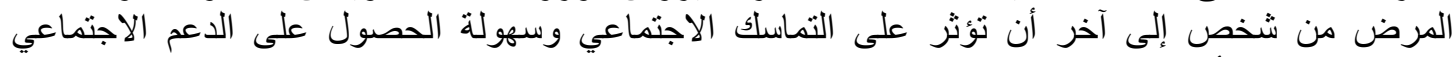

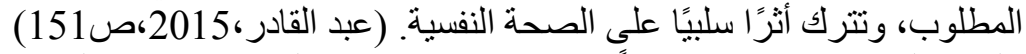

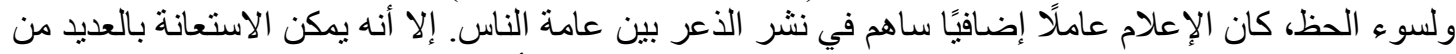

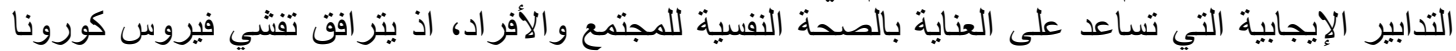

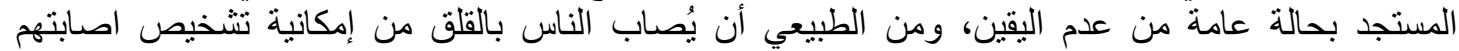
بالفايروس، إلى جانب القلق من إصابة أحد الأشخاص المقرئة المقين بالعدوى، و القلق من تعرض النفس أو المقربين

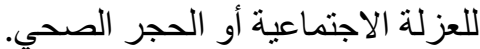

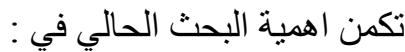

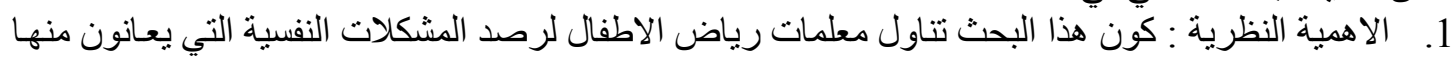

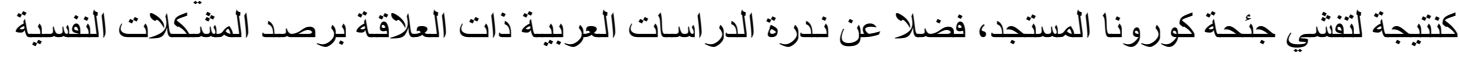

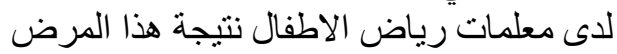

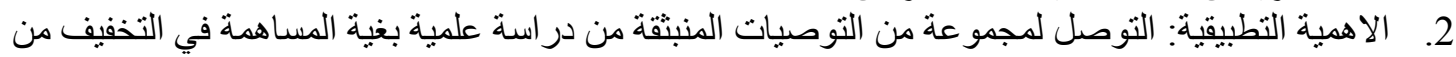

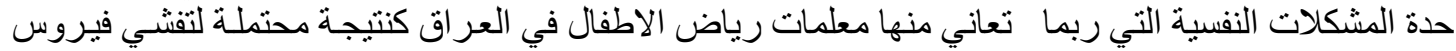

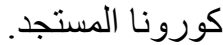
وتحددت مشكلة البحث لحالي بسؤ الين هما: 1. مـا طبيعـة المشكلات النفسية النـي تعـاني منها معلمـات ريـاض الاطفـال و المترتبـة على جائحسة كورونـا

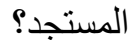
2. هل هناك اختلاف في نسبة المشكلات النفسية التي تعاني منها معلمات رياض الاطفال و المترتبة من جائحسة

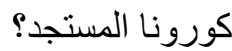

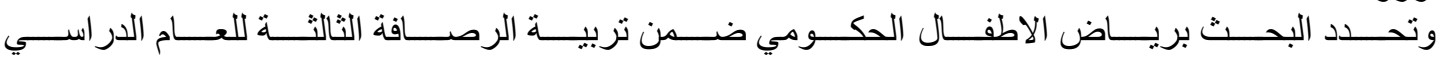
. 2020-2019) 


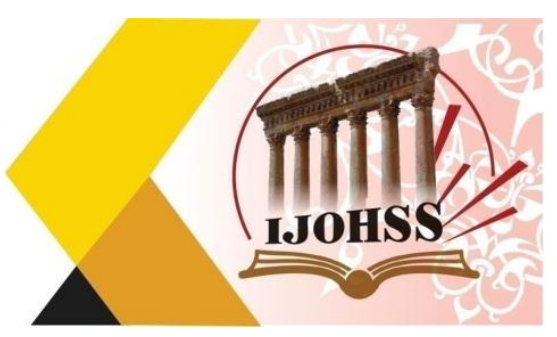

\title{
Corona Pandemic and its Psychological Impact on The Kindergarten Teacher
}

\author{
Dalal Jasim Abdul Ridha \\ Kindergarten \\ Ministry of Education - Iraq \\ Email: Irag.201197@gmail.com
}

\begin{abstract}
Fears about the transmission of the disease from one person to another can affect social cohesion and ease. Obtaining the required social support, and it has a negative impact on mental health. Unfortunately, the media was an additional factor that contributed to spreading panic among the general public. However, many positive measures can be used that help to take care of the mental health of society and individuals, as the outbreak of Corona virus is associated with The newcomer is in a general state of uncertainty, and it is natural for people to become anxious about the possibility of being diagnosed with the virus, along with anxiety that a close person will be infected with the infection, and anxiety that oneself or those close to being exposed to social isolation or quarantine Health.

The importance of the current research lies in:

1. The theoretical importance: the fact that this research deals with kindergarten teachers to monitor the psychological problems they suffer as a result of the outbreak of the new Corona pandemic, as well as the scarcity of Arab studies related to monitoring psychological problems of kindergarten teachers as a result of this disease 2. Application importance: reaching a set of recommendations emanating from a scientific study in order to contribute to alleviating the psychological problems that kindergarten teachers may suffer from in Iraq as a possible result of the outbreak of the new Corona virus.

The current research problem is defined by two questions:

1. What is the nature of the psychological problems that kindergarten teachers suffer from and resulting from the new Corona pandemic?

2. What are the most important psychological problems that kindergarten teachers suffer from and resulting from the new Corona pandemic?

The research was determined in governmental kindergartens within the third Rusafa education for the academic year (2019-2020 AD).
\end{abstract}

Keywords: Psychological problems, the emerging corona virus. 


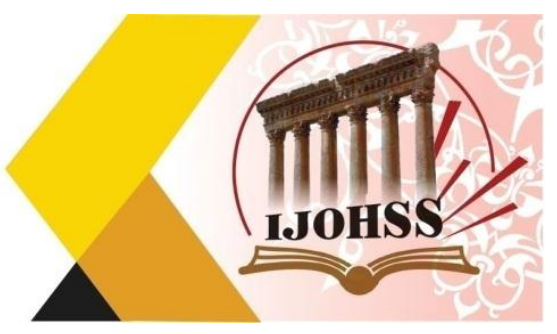

\section{المبحث اول/ الاطار النظري للبحث}

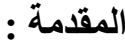

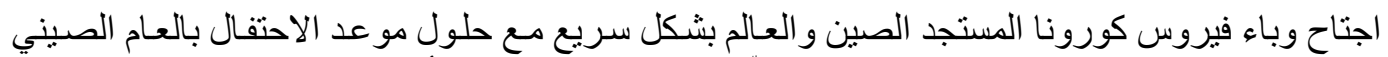

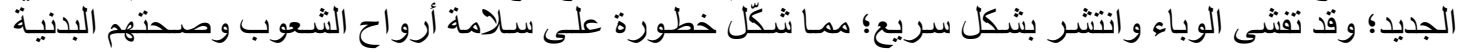

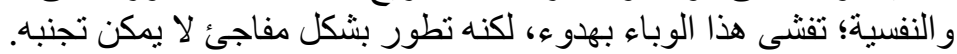

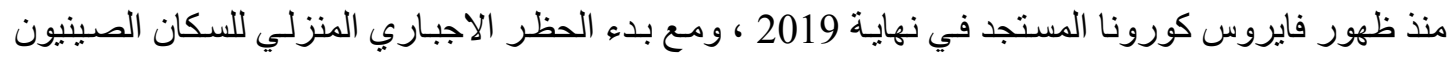

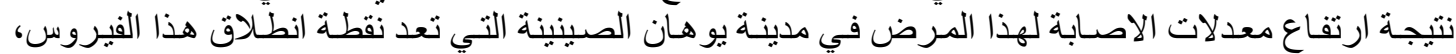

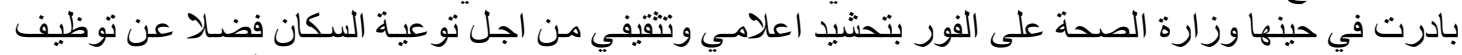

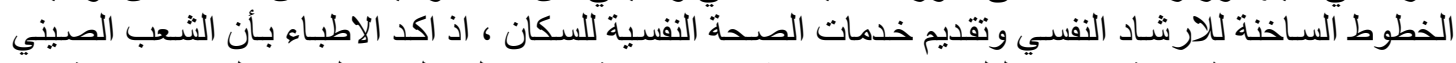

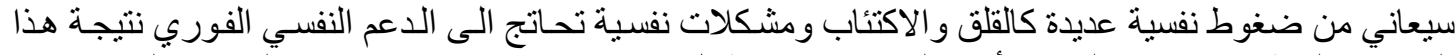

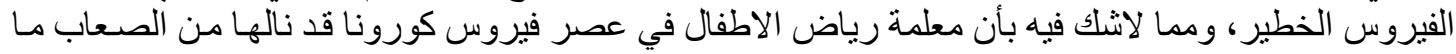

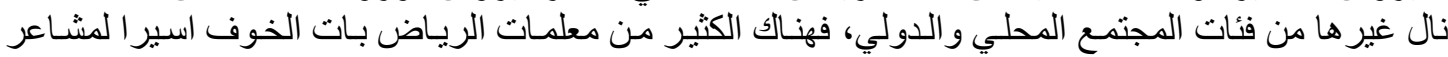

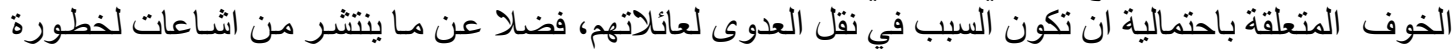

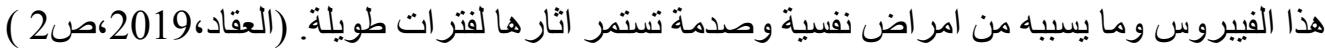

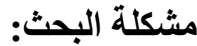
تتحدد مشكلة البحث لحالي بسو البحاتين هما: 3. مـا طبيعـة المشكلات النفسية التـي تعـاني منها معلمـات ريـاض الاطفـال و المترتبـة على جائحسة كورونـا

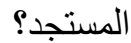
4. هل هناك اختلاف في نسبة المشكلات النفسية التي تعاني منها معلمات رياض الاطفال و المترتبة من جائحسة

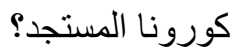

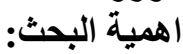

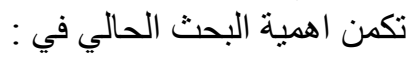

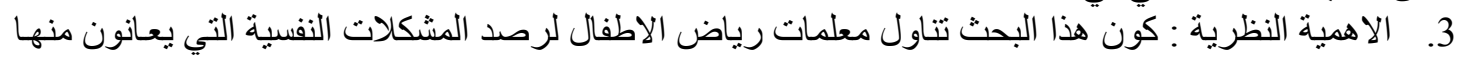

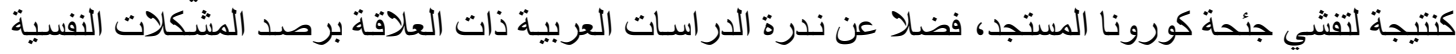

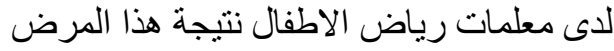

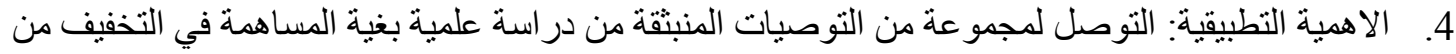

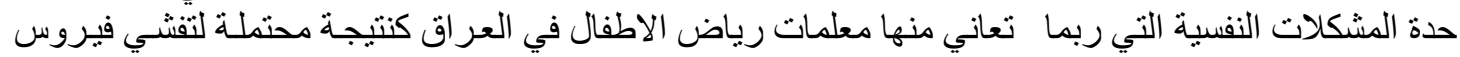

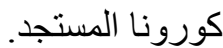

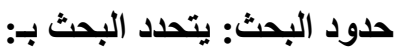

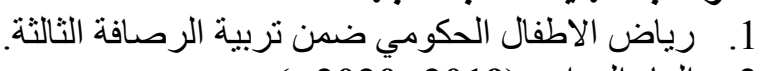

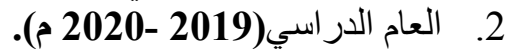

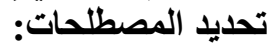

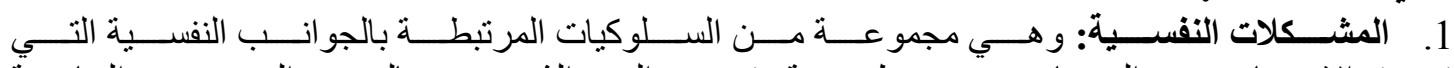

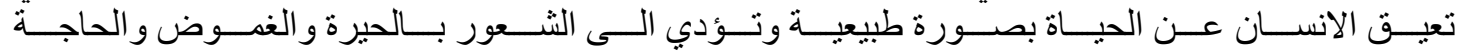

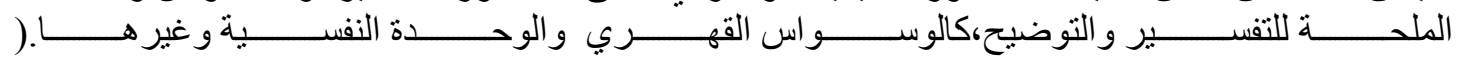
(WHO,2020,p22

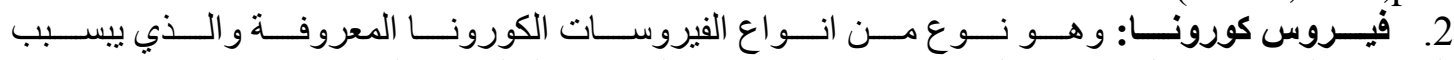

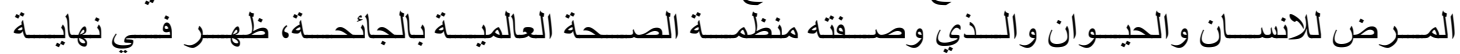

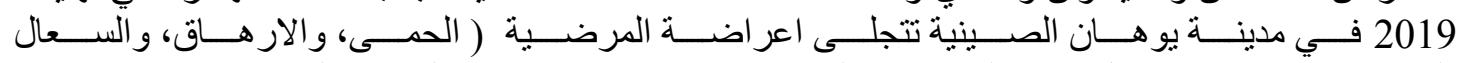

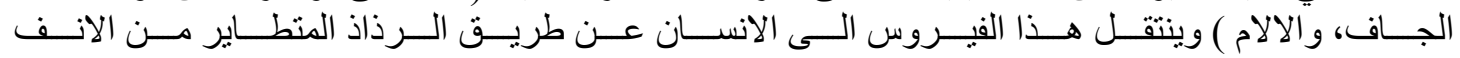

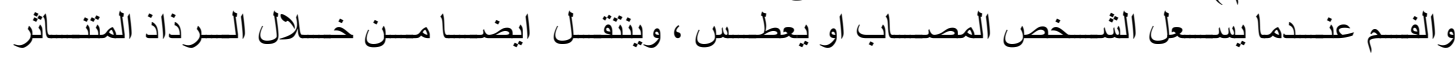

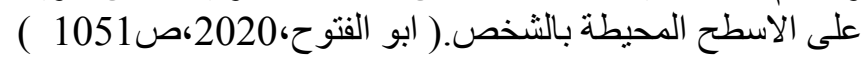




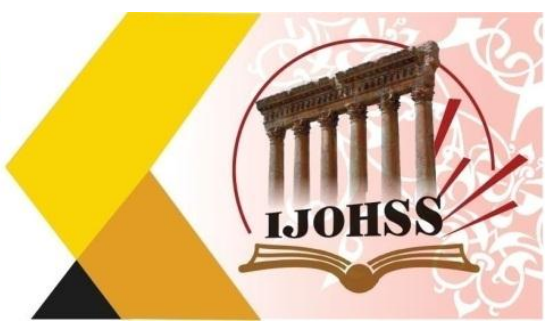

المبحث الثناني

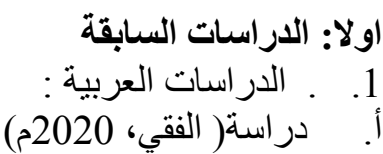

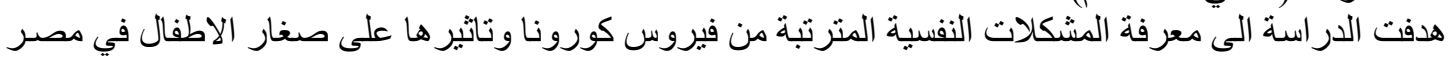

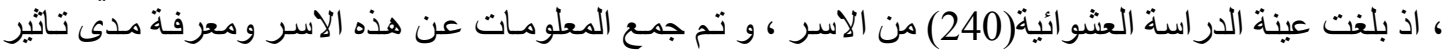

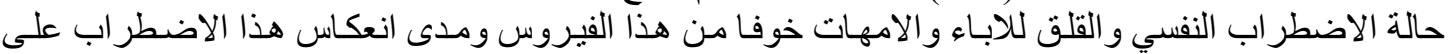

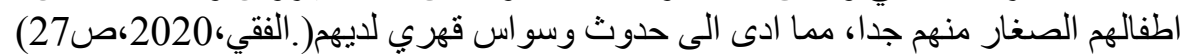

ب. ب. دراسة ( العكري،2020)

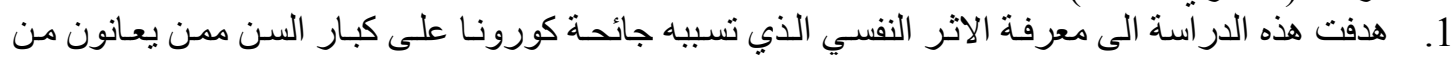

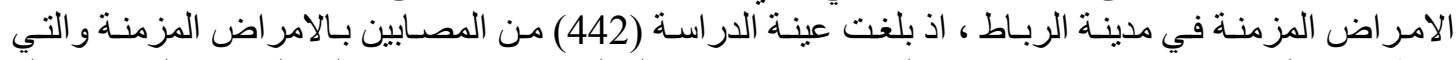

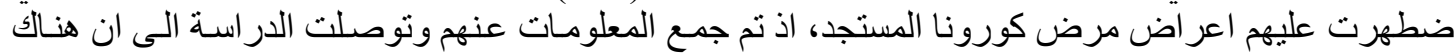

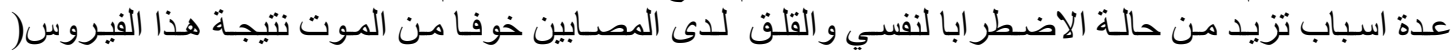

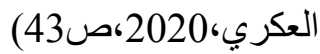

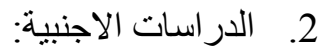
أ. أ. در اسة (Kang et al,2020)

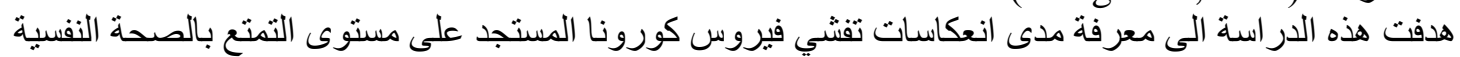

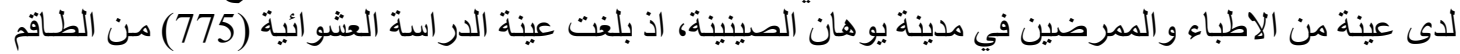

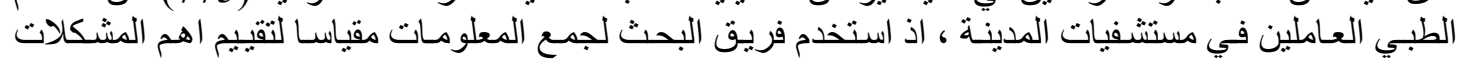

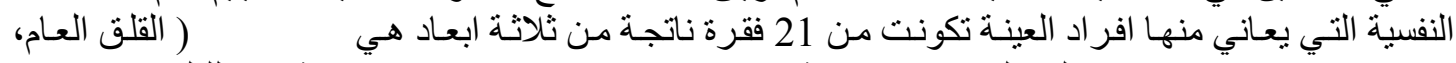

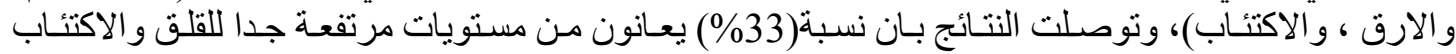

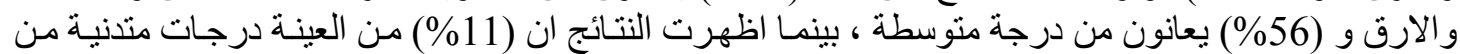

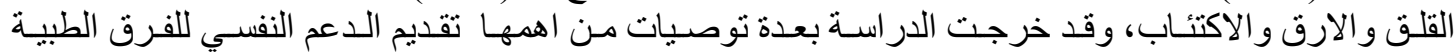

و الصحية في مدينة يو هان الصينية. (Kang et al,2020,p12)

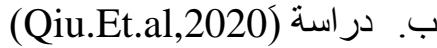

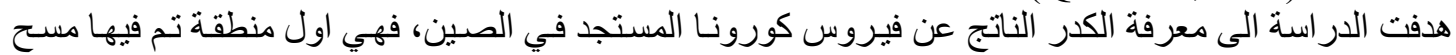

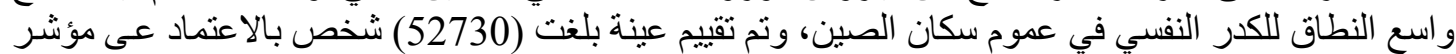

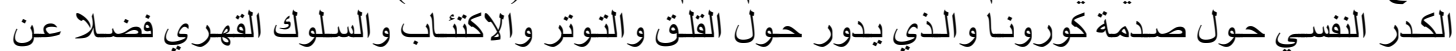

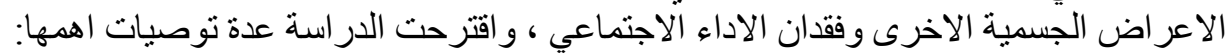

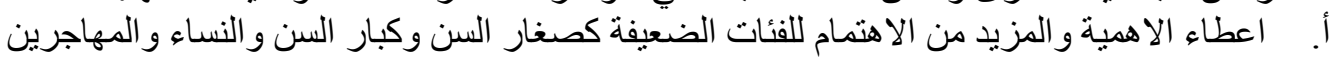

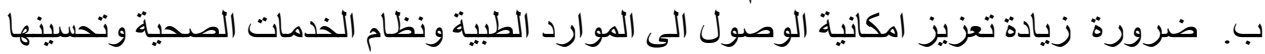

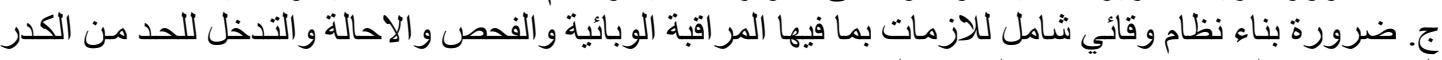
النفسي ومنع المزيد من مشكلات الصحة النفسية (Qiu.Et.al,2020.p33)

ثثانيا: المشاكل النفسية والعقلية المترتبة من جائحة كورونا لاى افراد المجتمع:

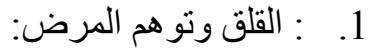

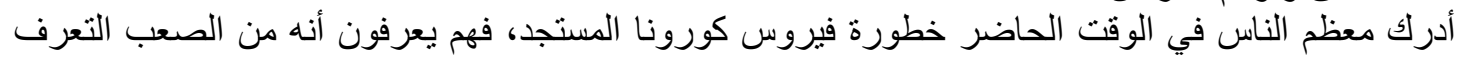

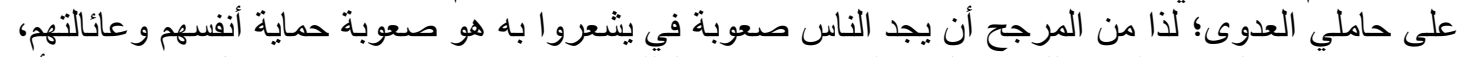

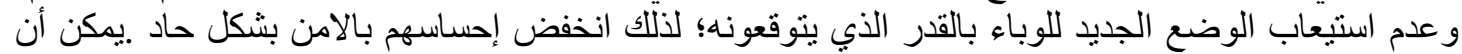

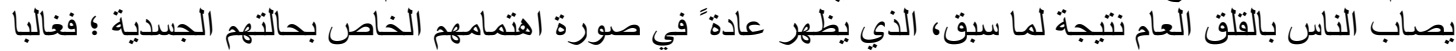

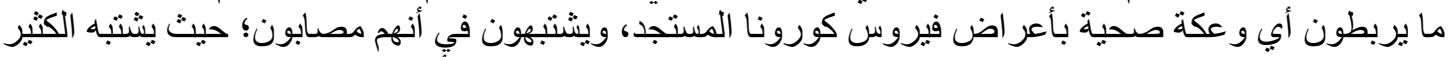

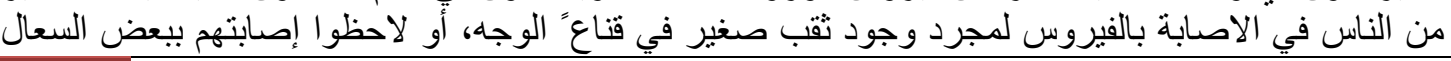




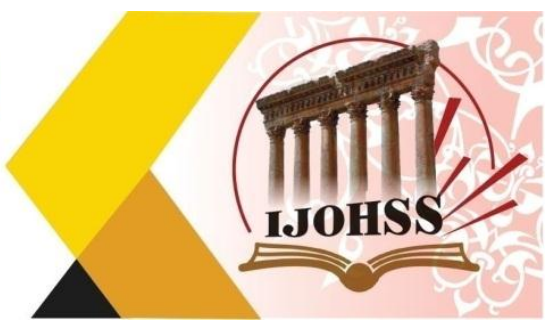

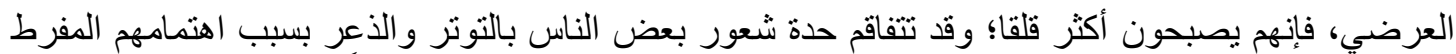

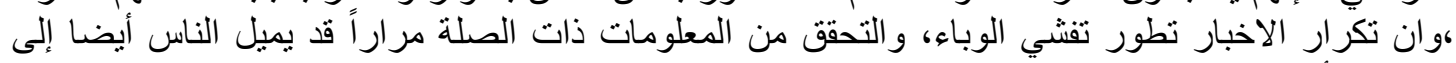

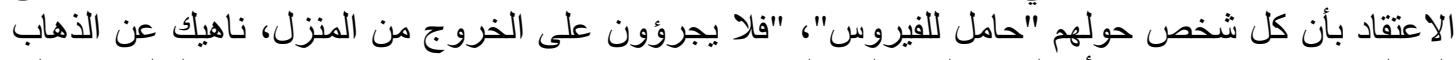

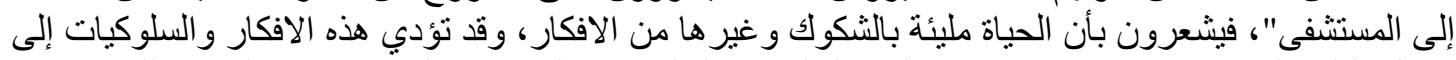

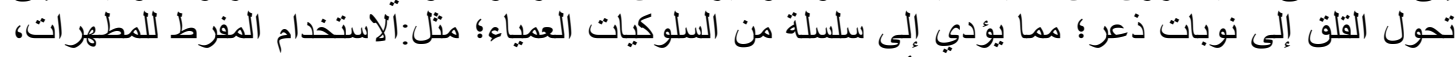

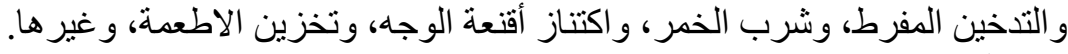
2. 2. 2.

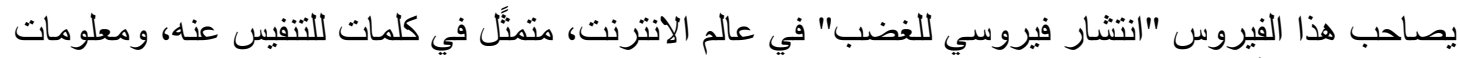

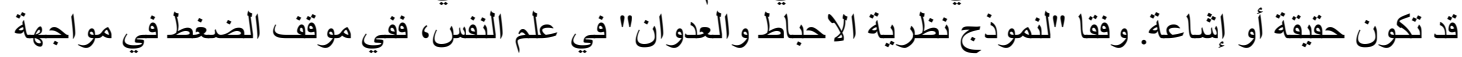

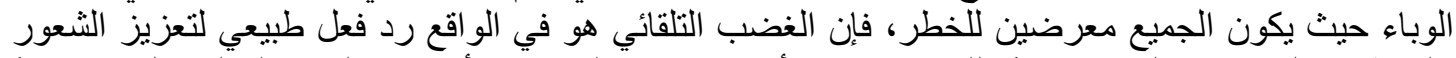

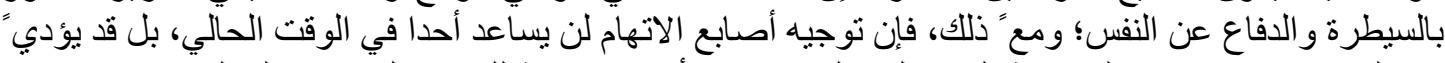

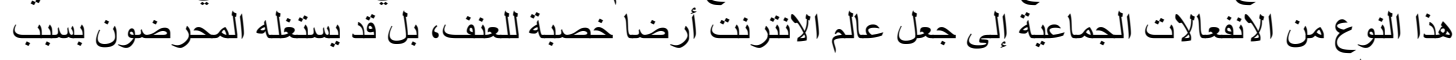

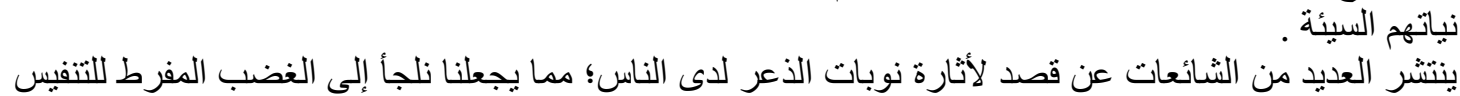

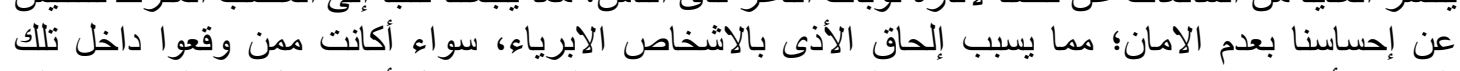

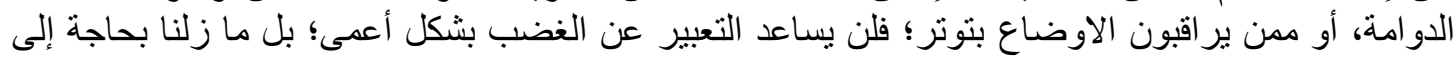

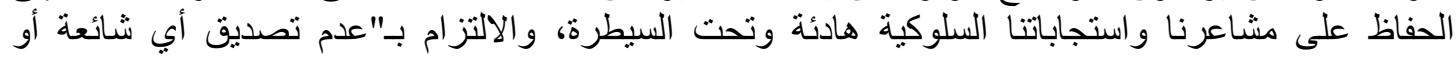
نشر ها"، وتتبع الوضع الحالي للوباء بعاء بعلانية.

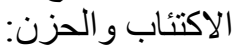

يشعر الكثير من الناس في الحجر الصحي و الذين لا يخرجون من المنزل بالاكتئاب و الحزن و اليأس،

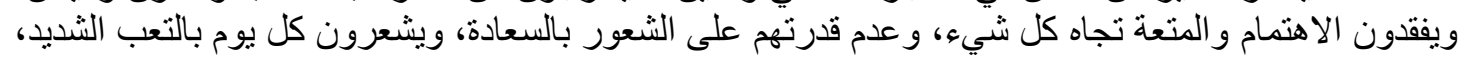

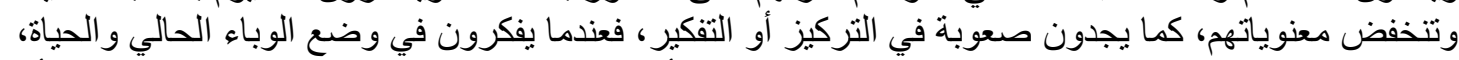

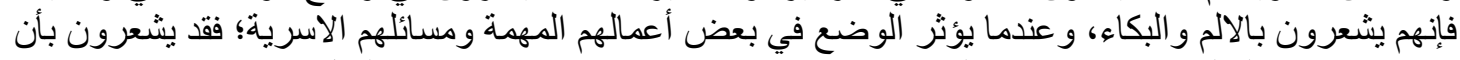

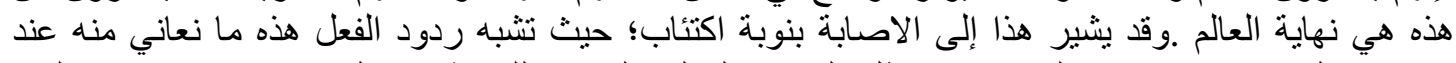

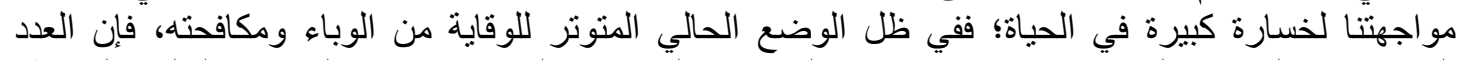

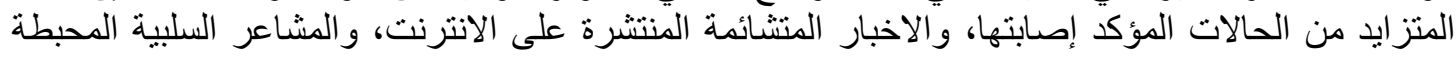

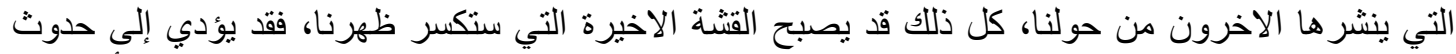

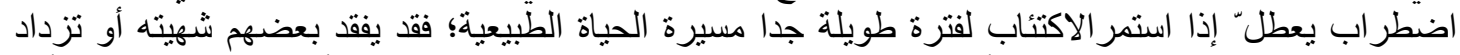

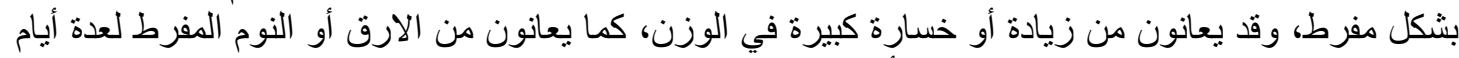

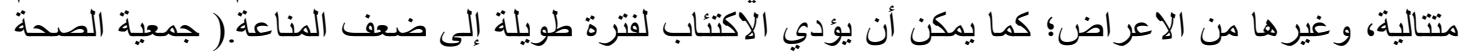
النفسية الصينية، 2019،صنية من الاعرضك

\section{المبحث الثالث منهجية البحث واجرائته}

تحددت منهجية البحث الحالي باستخدام المنهج الوصفي باسلوب المسح الميداني لانه المانه من افضل المناهج وايسر ها

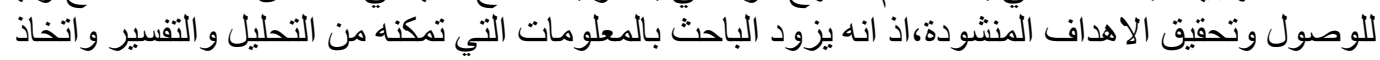

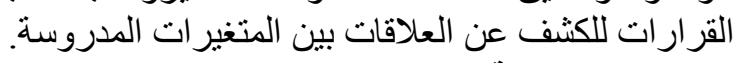
1.

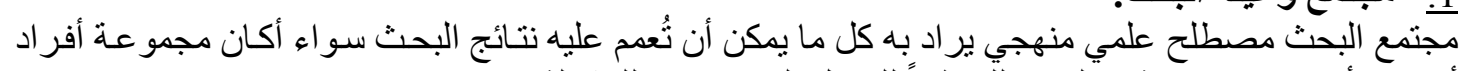

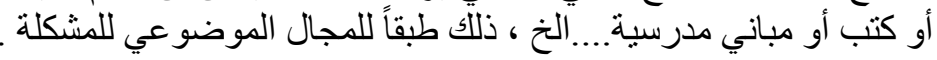




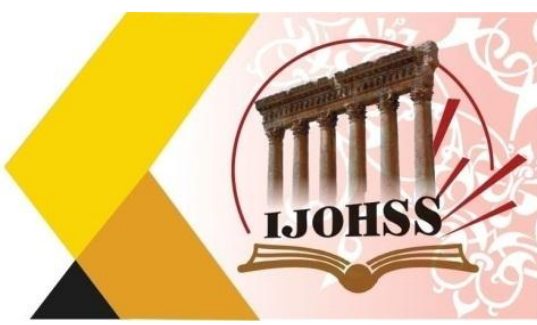

يتكون مجتمع البحث من معلمات رياض الاطفال الحكومي للعام الدر اسي (2019-2020) في مدينة بغداد (الرصافة الثالثة )ومجموعهم (70). الجدول (1).

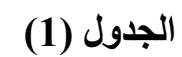

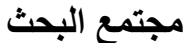

\begin{tabular}{|c|c|c|}
\hline العدد & اسم الروضة & $ت$ \\
\hline 10 & البلابل & 1 \\
\hline 10 & البستان & 2 \\
\hline 10 & الجنان & 3 \\
\hline 10 & الفردوس & 4 \\
\hline 10 & العسل & 5 \\
\hline 10 & الكناري & 6 \\
\hline 10 & البهجة & 7 \\
\hline 10 & السعادة & 8 \\
\hline 10 & الرياحين & 9 \\
\hline 10 & عطر الورد & 10 \\
\hline 100 & 10 & المجموع \\
\hline
\end{tabular}

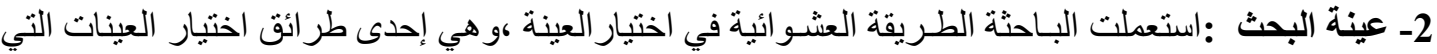

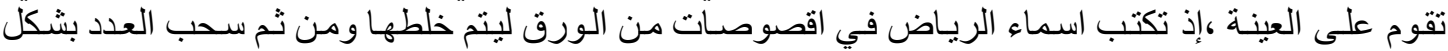

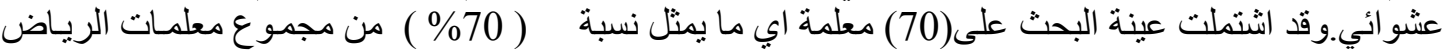

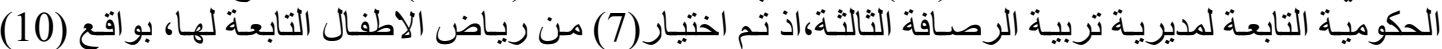

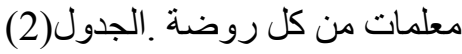

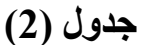

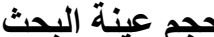

\begin{tabular}{|c|c|c|}
\hline عدد الاسر الاطفال & اسم الروضة & \\
\hline 10 & البلابل & 1 \\
\hline 10 & الكناري & 2 \\
\hline 10 & البهجة & 3 \\
\hline 10 & الجنان & 4 \\
\hline 10 & الفردوس & 5 \\
\hline 10 & السعادة & 6 \\
\hline 10 & روضة & 7 \\
\hline 70 & المجموع & \\
\hline
\end{tabular}

الجدول من عمل الباحثة بالاعتماد على : وزراة التربية ، قسم الاحصاء المدرسي، 2020، بيا نات غير منشورة

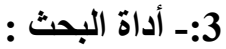

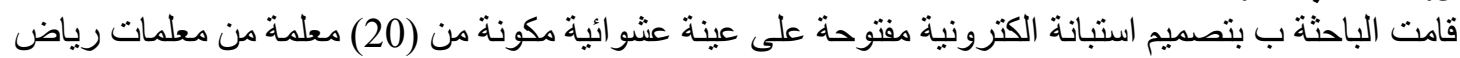

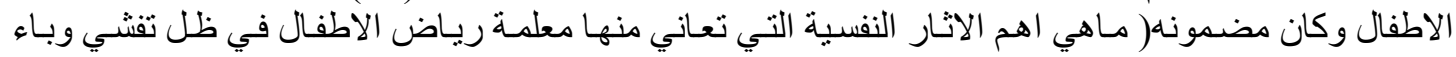




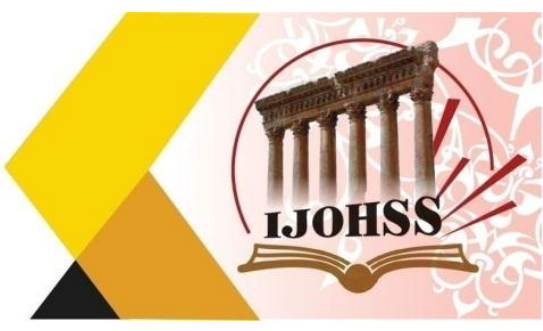

كورونا، هل هناك تغيرات في نومك؟ أو طعامك أو مشاعرك منذ بداية الحظر المنزلي، وحظر التجو ال؟ ) كاداداة

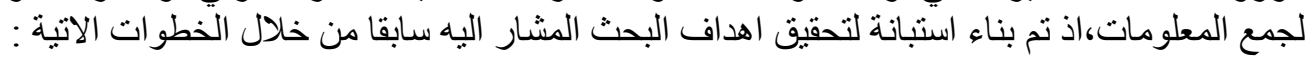

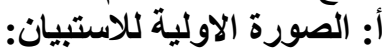

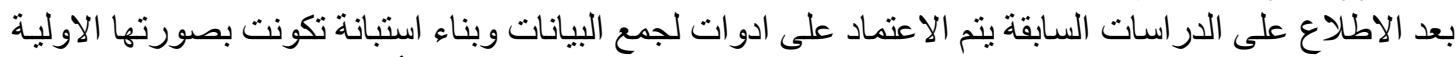

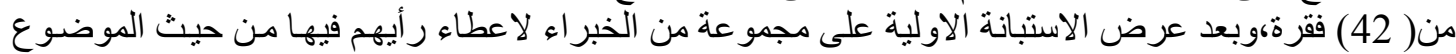

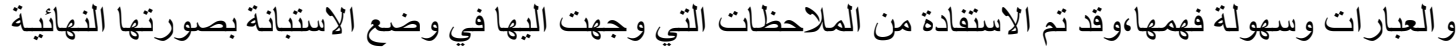

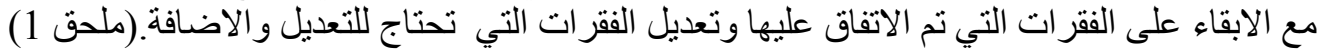
ب: ب الصورة النهائية للاستبيان:

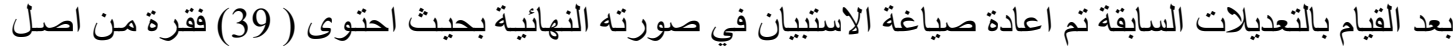

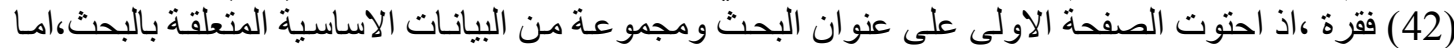

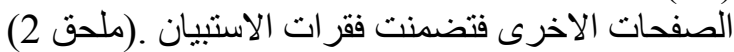

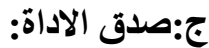

اكتفت الباحثة بالصدق الظاهري على اساس ار اء الخبر اء في حكمهم على فقر ات الاستبانة، لتحديد مدى ملائمـة

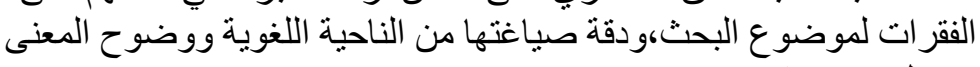

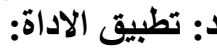

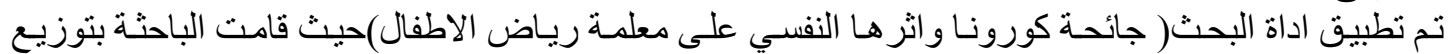

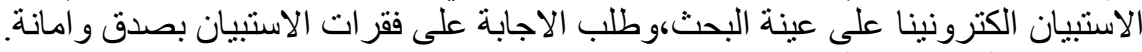
هـ: المعالجة الاحصائية: قامت الباحثة باستخدام النسبة المئوية = عدد الاجابة على الفقرات × 100\%

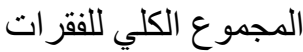

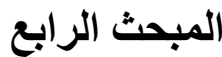

عرض النتائج وتحليلها

يتضمن هذا الفصل عرض النتائج التي توصلت اليها الباحثة على وفق الاهداف المرسومة ومناقثتها وتفسير ها

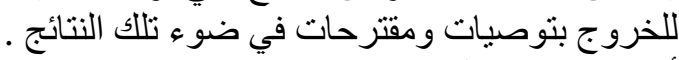

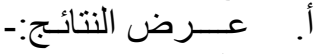

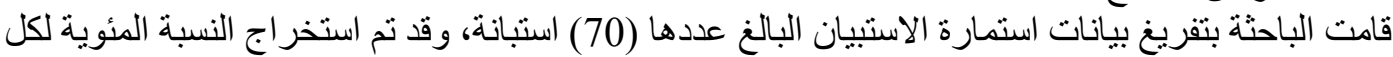

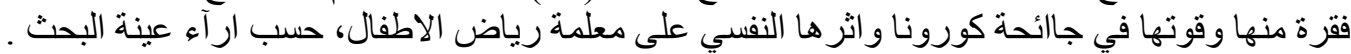
تعاني معلمة رياض الاطفال من بعض المشكلات النفسية ( الوسو اس القهري، الاكتئاب، الكدر النفسي، الثعور بالوحدة النفسية،، اضطر ابات الطعام،اضطر ابات النوم، المخاوف الاجتماعية) التي تترتب على جائحة فايروس النعرس

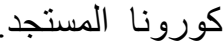

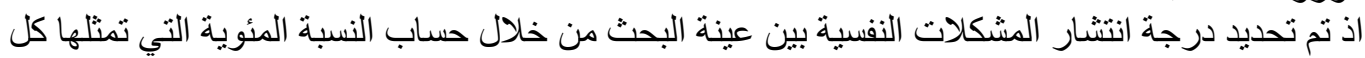

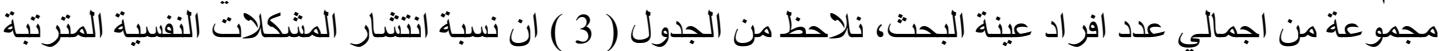

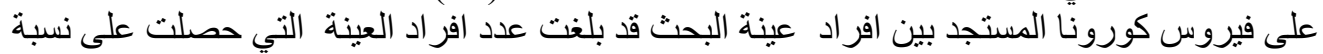

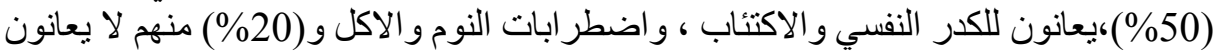
اما للمخاوف الاجتماعية فقد بلغت النسبة (60\%) منهم من يعانون هذه المخاوف في حين (10\%) لا بعانون

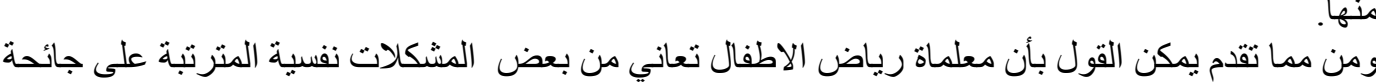

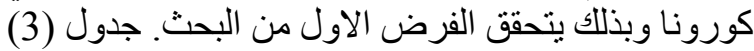




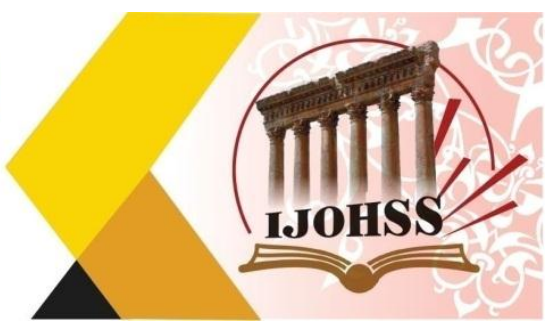

( هل هنالك اختلاف في نسبة المشكلات النفسية المنرتبة من جائحة كورونا ( الثعور بالوحدة النفية النفية،

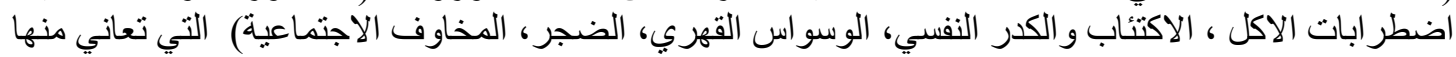

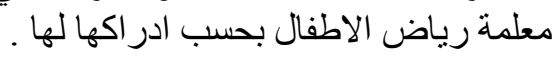

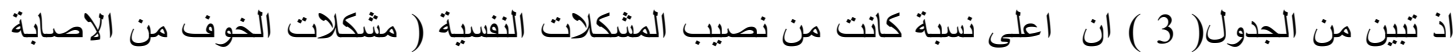

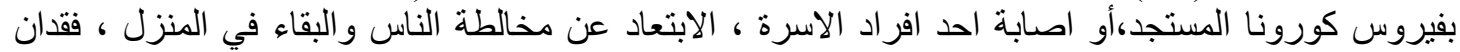

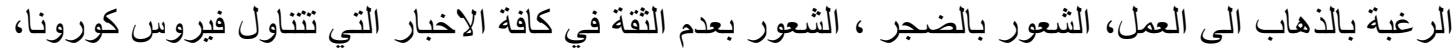

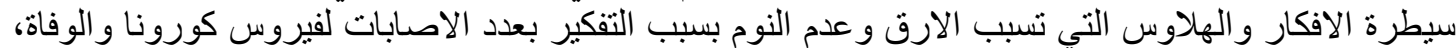

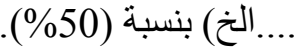
في حين حصلت المشكلات الاخرى ( عدم المشاركة في المناقثات حول الفيروس، عدم القيام بالزيارات

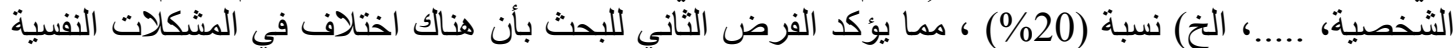
التي تعاني منها معلمات رياض الاطفال .جدول (3).

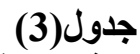

التحليل الاحصائي للمشكلات النفسية المتلاتبة على فيروس كورونا المستجد لاى عينة البحث

\begin{tabular}{|c|c|c|c|c|c|c|}
\hline$\%$ & $\gamma$ & $\%$ & نعم & الفقرة & البعد & ت \\
\hline 20 & 20 & 50 & 50 & اصبحت ابتعد عن الناس و ابقى في المنزل بعد انتشار فيروس & \multirow{5}{*}{ 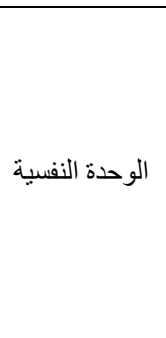 } & .1 \\
\hline 30 & 30 & 40 & 40 & لا اهتم بمعرفة نسبة الوفيات او المتعافين من الفيروس & & .2 \\
\hline 20 & 20 & 50 & 50 & لا اشترك في المناقثات حول فيروس كورونا او اب موضو ع اخر & & .3 \\
\hline 20 & 20 & 50 & 50 & اعتقد ان هذا الفيروس هو مكافأ لنا لكي نعيش بمعزل عن العالم & & .4 \\
\hline 10 & 10 & 60 & 60 & افضل التعليم الالكتورني بدلا من ذهابي للروضة لتفادي الاصابة & & .5 \\
\hline 30 & 30 & 40 & 40 & اشعر بالغثيان عندما تفكر احدى صديقاتي بزيارتي في ظل انتشار & \multirow{6}{*}{ الاجتماعية المخاف } & .6 \\
\hline 40 & 40 & 30 & 30 & اتصنع المرض عندما يطلب مني الذهاب الى الروضة ( العمل) & & .7 \\
\hline 10 & 10 & 60 & 60 & امتنع عن الخروج من منزلي عندما اعلم ان الفيروس يقترب من & & .8 \\
\hline 10 & 10 & 60 & 60 & 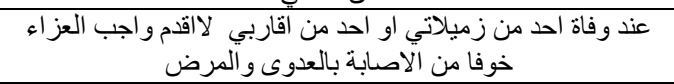 & & .9 \\
\hline 0 & 0 & 70 & 70 & اخاف بشدة على صحتي وصحة اسرتي من هذا الفيروس & & .10 \\
\hline 20 & 20 & 50 & 50 & لا اصافح اي شخص خوفا من الاصابة بالمرض و العدوى & & .11 \\
\hline 10 & 10 & 60 & 60 & ليس لدي الطاقة للذهاب الى العمل مرة اخرى في ظل معدلات الفيروس & \multirow{12}{*}{ الاكتثاب و الكنر } & .12 \\
\hline 50 & 50 & 20 & 20 & المعلومات المقدمة عبر وسائل الاعلام العالمية و المحلية عن فيروس & & .13 \\
\hline 30 & 30 & 40 & 40 & 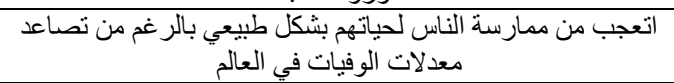 & & .14 \\
\hline 0 & 0 & 70 & 70 & ثقافة المجتمع لاتدربنا على كيفية التعامل مع الاوبئة & & .15 \\
\hline 10 & 10 & 60 & 60 & وسائل الاعلام لاتساهم في نشر الوعي بخطورة هذا الفيروس بين & & .16 \\
\hline 0 & 0 & 70 & 70 & يز عجني متابعة اخبار فيروس كورونا في العالم & & .17 \\
\hline 0 & 0 & 70 & 70 & لايوجد اهتمام من قبل وزارة التزبية بتوعية الكو ادر التدريسة لكيفية & & .18 \\
\hline 40 & 40 & 30 & 30 & اعتقل ان اهدافي في الحياة غير جديرة بالتفعيل & & .19 \\
\hline 20 & 20 & 50 & 50 & احس ان مناعتي النفسية لَّو اجهة فيروس كورونا اصبحت ضعيفة & & .20 \\
\hline 10 & 10 & 60 & 60 & لم تعد لاي اي رغبة بالعمل خوفا من الاصابة بالفيروس & & .21 \\
\hline 30 & 30 & 40 & 40 & لم يعد هنالك شي يدخل السرور على قلبي & & .22 \\
\hline 20 & 20 & 50 & 50 & اشعر ان كل ماتعلمته خلال مسيرني التعليمية لايفيدني في كيفية انقاذ & & .23 \\
\hline
\end{tabular}


المجلة الحولية اللملوم الانسانية والإمتاعية International Journal on Humanities and Social Sciences website:www.ijohss.com Email:editor@ijohss.com ISSN: $2415-4822$

العدد (29) يناير 2022

Volume (29) January 2022

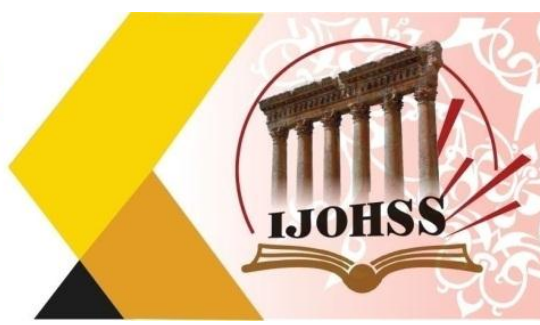

\begin{tabular}{|c|c|c|c|c|c|c|}
\hline & & & & نفسي من فيروس كورونا & & \\
\hline 30 & 30 & 40 & 40 & عندما تصاب احدى زمبالاتي في العمل اشعر انتي لم اقم بدروي & \multirow{5}{*}{ الوسو اس القهري } & .24 \\
\hline 10 & 10 & 60 & 60 & يجب تعقيم الروضة لاني اشعر ان الفيروس منتثر فيها & & .25 \\
\hline 20 & 20 & 50 & 50 & اقوم بتعقيم مكان جلوسي في الروضة لاكثر من مرة & & .26 \\
\hline 20 & 20 & 50 & 50 & اغسل يدي عشر ات المر ات و اعقمها للوقاية من الفيروس & & .27 \\
\hline 40 & 40 & 30 & 30 & اشعر ان هذا الفيروس سيصاب به الجميع وقد يؤدي الى موتهم فلماذا & & .28 \\
\hline 10 & 10 & 60 & 60 & الافكار و الهلاوس تطاردني ليلا عن مصير من مات جر اء هذا & \multirow{6}{*}{ 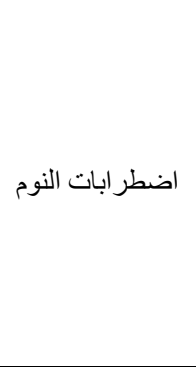 } & .29 \\
\hline 30 & 30 & 40 & 40 & اخاف ان اغمض عيني حتى لا اسمع خبار موت احدى زميلاتي في & & .30 \\
\hline 20 & 20 & 50 & 50 & اشعر بالانهاك الثديد نتيجة تفكيري طو ال الليل بما سمعته فيروس & & .31 \\
\hline 20 & 20 & 50 & 50 & اجد صعوبة في دخولي للنوم بعد مشاهدتي لاخبار فيروس كورونا & & .32 \\
\hline 10 & 10 & 60 & 60 & نومي متقطع بسبب كثرة تفكيري في احتمالية اصابتي بفيروس & & .33 \\
\hline 10 & 10 & 60 & 60 & اركز قبل النوم في عدد الوفيات اكثر من عدد المتعافين من الفيروس & & .34 \\
\hline 30 & 30 & 40 & 40 & لبس لدي اي رغبة في الطعام خاصة بعد سماعي اخبار انتشار & \multirow{5}{*}{ اضطر ابات الطعام } & .35 \\
\hline 40 & 40 & 30 & 30 & الطعام متعهه و علينا الاستمتاع به قبل نهاية العالم & & .36 \\
\hline 20 & 20 & 50 & 50 & اشعر ان وزني زاد بعد انتشار فيروس كورونا & & .37 \\
\hline 10 & 10 & 60 & 60 & اصبح استهلاكي للمو اد الغذائية قد ازداد الى الضعف عما كان عليه & & .38 \\
\hline 20 & 20 & 50 & 50 & اشغل نفسي بصنع العديد من الاكلات هروبا من سماع الاخبار عن & & .39 \\
\hline
\end{tabular}

مناقشة النتائج:

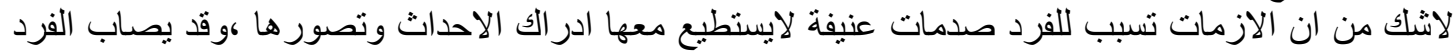

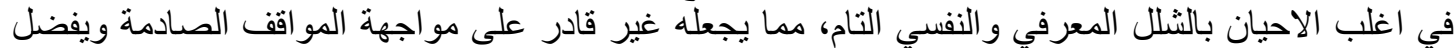

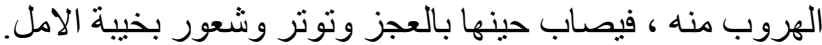

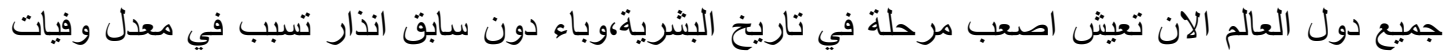

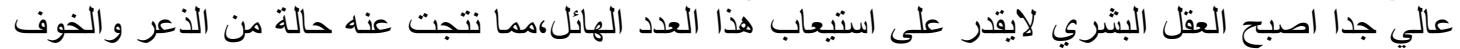

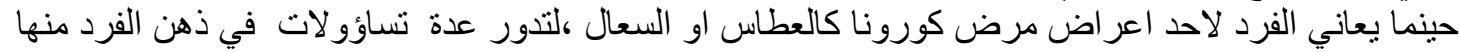

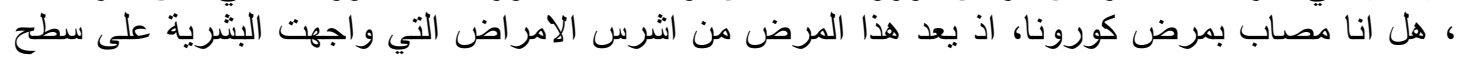

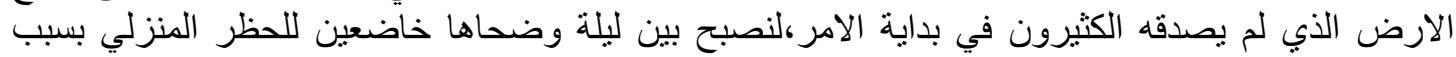

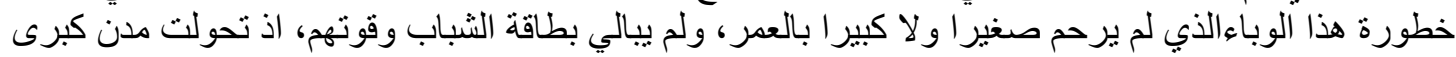

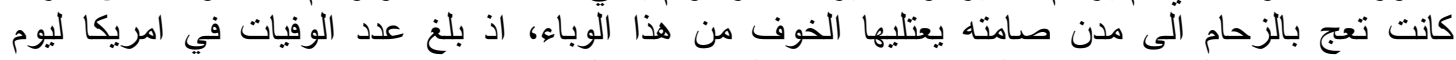

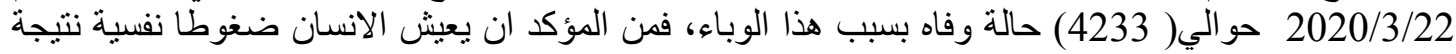
هذا الوباء و المخاوف الناتجة عنه.

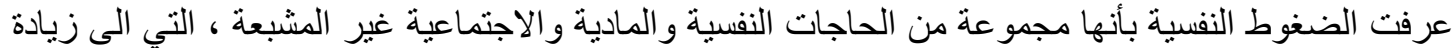

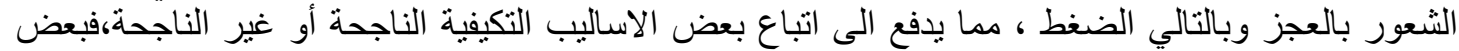

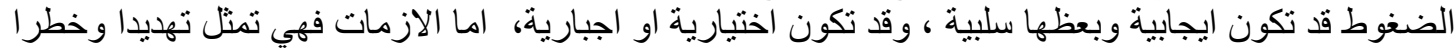

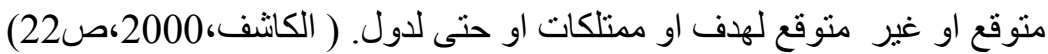

الاستنتاجاث

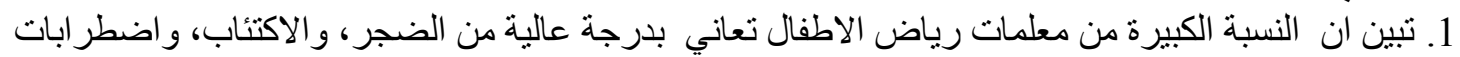

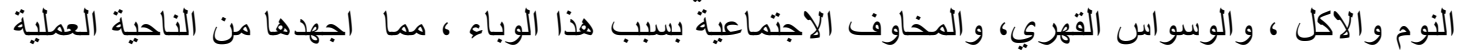




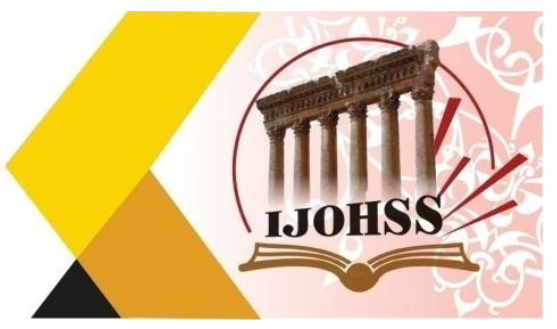

و المجتمعية، فخلق عندها حالة من الخوف و العجز وعدم القدرة على التكيف الايجابي مع متغيرات الحياة

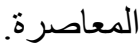

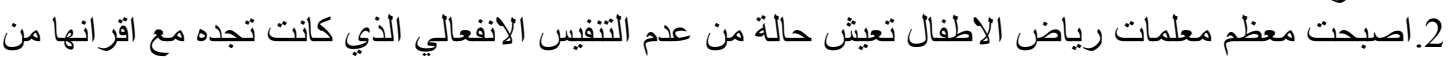

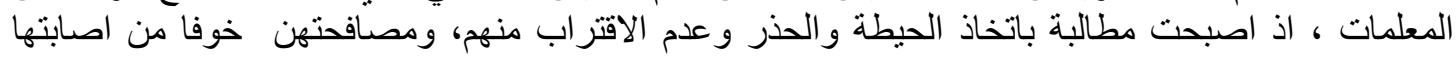

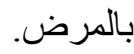
التوصيات

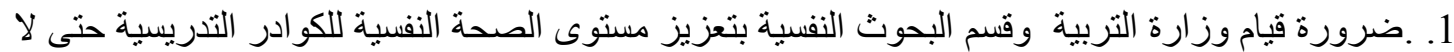

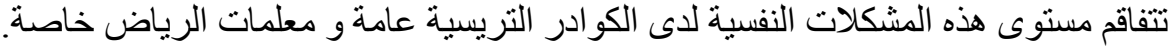

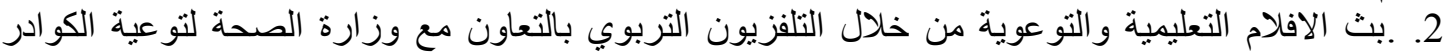

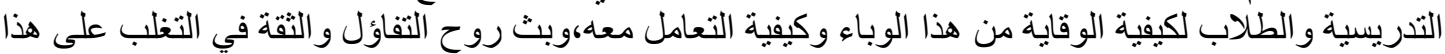

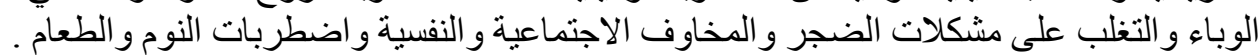

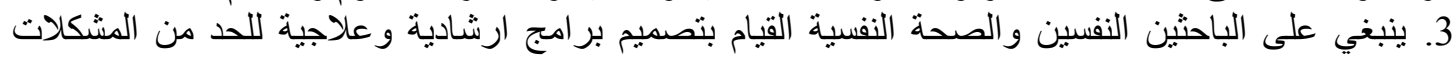

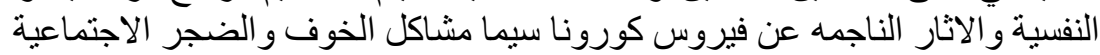

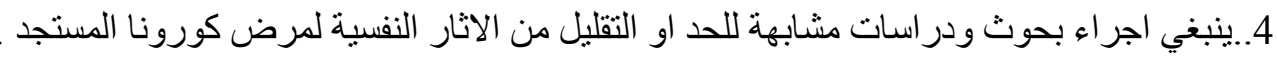

14. المصادر الفنو ح، محمد كمال، المشكلات النفسية المترتبـة على جائحسة كورونـا المستجد، المجلة التربويـة، العدد 2. جمعية الصحة النفسية الصينية، دليل فعالية الصحة النفسية من فيروس كورونـا، ترجمـة امينـة شكري، بيت

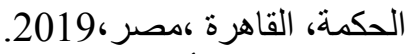
3. عبدالقادر، أبوبكر ساسي، الوسو، اس القهري بين الاسباب والعلاج، مجلـة المعرفة، جامعة الزيتونـة ، كلية

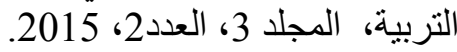

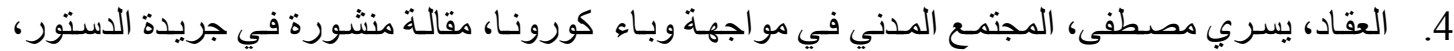

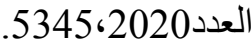

5. العكري، احمد محمود، الاثار النفسية المترتبة من فيروس كورونا على كبار السن ، مجلة البحوث النفسية،

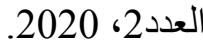
6. الفقي، آمال ابر ابيم ، فعالية الارشاد التربو ي في إدارة الضجر لدى طالب الجامعة المتفوقين. مجلة التربية

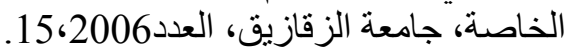

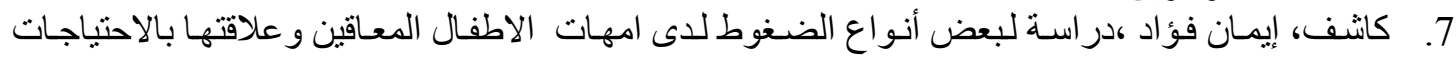

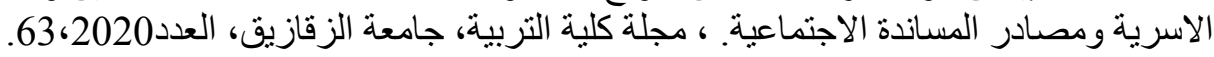

8. Kang, L. ; Ma, S. ; Chen, M. ; Yang, J. ; Waing, Y. ; Ruiting, L. et al., (2020). Impact on mental health and perceptions of psychological care among medical and nursing staff in Wuhan during the 2019 novel coronavirus disease outbreak: A crosssectional study. Brain, Behavior, and Immunity, Available online 30 March 2020, In Press, Corrected Proof.

9. Qiu, J., Shen, B., Zhao, M. ,Wang, Z., Xie, B., \& Xu, Y. (2020) A nationwide survey of psychological distress among Chinese people in the COVID-19 epidemic: implications and policy recommendations. General Psychiatry, 33, 2, 1-3

10. WHO (2002). The World Health Report 2002: Reducing Risks, Promoting Healthy Life. Geneva. 


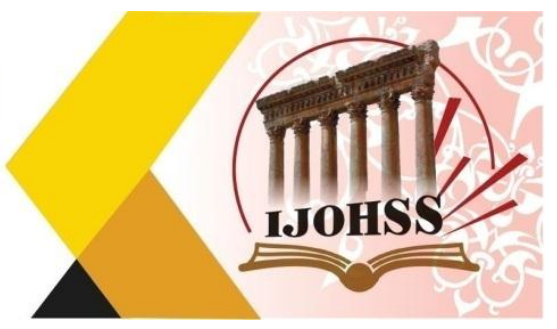

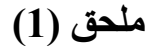

استبانة الاختبار بصيغته الاولية (جائحة كورونا واثرها النفسي على معلمة رياض الاطفال)

\begin{tabular}{|c|c|c|c|}
\hline كلا & نعم & الفقترة & 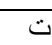 \\
\hline & & اصبحت ابتعد عن الناس وابقى في المنزل بعد انتثار فيروس كورونا & .1 \\
\hline & & لا الهتم بمعرفة و نسبة الوفيات او المتعافين من الفيروس & .2 \\
\hline & & لا اشترك في المناقثنات حول فيروس كورونا او اي موضوع اخر مع زميلاتي & .3 \\
\hline & & أعتقد ان هذا الفبروس هو مكافا لنا لكي نعيش بمعزل عن العالم المريض & .4 \\
\hline & & افضل التعليم الالكتورني بدلا من ذهابي للروضة لتفادي الاصابة بالمرض & .5 \\
\hline & & اشعر بالغثيان عندما تفكر احدى صديقاتي بزيارتي في ظل انتثار المرض & .6 \\
\hline & & اصبح الاشخاص من حولي سيء الطباع & .7 \\
\hline & & تنتابنب فكرة الانتحار بدلا من موتي بهذا الفيروس & .8 \\
\hline & & اعتقد ان لا احد يستحق المساعدة في هذا العالم خاصة بعد انتشار كورونا & .9 \\
\hline & & اتصنع المرض عندما يطلب مني الذهاب الى الروضة ( العمل) & .10 \\
\hline & & امتتع عن الخروج من منزلي عندما اعلم ان الفيروس يقترب من مكان اقامتي & .11 \\
\hline & & عند وفاة احد من زميلاتي او احد من اقاربي لااقدم واجب العز اء خوفا من الاصابة بالعدى & .12 \\
\hline & & اخاف بثدة على صحتي وصحة اسرتي من هذا الفيروس & .13 \\
\hline & & لا اصافح اي شخص خوفا من الاصابة بالمرض و العدوى & .14 \\
\hline & & ليس لدي الطاقة للأهاب الى العمل مرة اخرى في ظل معدلات انتشار الفيروس & .15 \\
\hline & & المعلومات المقدمة عبر وسائل الاعلام العالمية والمحلية عن فيروس كورونا كاذبة & .16 \\
\hline & & اتعجب من ممارسة الناس لحياتهم بشكل طيبعي بالر غم من تصاعد معدلات الوفيات في العالم & .17 \\
\hline & & تثقافة المجتمع لاتدربنا على كيفية التُعامل مع الاوبئة & .18 \\
\hline & & وسائل الاعلام لاتساهم في نشر الو عي بخطورة هذا الفيروس بين افراد المجتمع & .19 \\
\hline & & بز عجني مثابعة اخبار فيروس كورونا في العالم & .20 \\
\hline & & لايوجد اهتمام من قبل وزارة التزبية بتو عية الكى ادر التندريسة لكيفية الوقاية من الفيروس & .21 \\
\hline & & اعتقد ان اهدافي في الحياة غير جديرة بالتفعيل & .22 \\
\hline & & الحس ان مناعتي النفسية لَو أجهة فيروس كورونا اصبحت ضعيفة & .23 \\
\hline & & لم تعد لدي آي ر غبة بالعطل خوفا من الاصابة بالفيروس & .24 \\
\hline & & لم يعد هناك شي يذخل السرور على قلبي & .25 \\
\hline & & اشعر ان كل ماتعلمته خلال مسبرتي التعليمية لايفيدني في كيفية انقاذ نفسي من فيروس كورونا & .26 \\
\hline & & 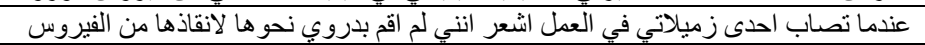 & .27 \\
\hline & & يجب تعقيم الروضة لاني اشعر ان الفيروس منتشر فيها & .28 \\
\hline & & اقوم بتعقيم مكان جلوسي في الروضة لاكثر من مرة & .29 \\
\hline & & اغسل يدي عشرات المرات واعقمها للوقاية من الفيروس & .30 \\
\hline & & اشعر ان هذا الفيروس سيصاب به الجميع وقد يؤدي الى موتهم فلماذا نذهب للعمل & .31 \\
\hline & & الأفكار والهلاوس تطاردني لبلا عن مصير من مات جراء هذا الفيروس & .32 \\
\hline & & اخاف ان اغمض عيني حتى لا اسمع خبار موت احدى زميلاتي في العطل & .33 \\
\hline & & اشتعر بالانهاك الثديد نتنيجة تفكيري طو ال الليل بما سمعته فيروس كورونا & .34 \\
\hline & & اجد صعوبة في دخولي للنوم بعد مشاهدتي لاخبار فيروس كورونا & .35 \\
\hline & & نومي متفطع بسبب كثرة تفكيري في احتمالية اصابتي بفيروس كورونا & .36 \\
\hline & & اركز قبل النّوم في عدد الوفيات اكثر من عدد الدتعافين من الفيروس & .37 \\
\hline & & ليس لدي ابي رغبة في الطعام خاصة بعد سماعي اخبار انتثار فيروس كورونا & .38 \\
\hline & & الطعام متعها و علينا الاستمتاع به قبل نهاية العالم & .39 \\
\hline & & الشعر ان وزني زاد بعد انتشار فيروس كورونا & .40 \\
\hline & & اصبح استهلاكي للمو اد الغذائية قد ازداد الى الضعف عما كان عليه قبل انتثار فيروس كورونا & .41 \\
\hline & & اشغل نفسي بصنع العديد من الاكلات هروبا من سماع الاخبار عن فيروس كورونا & .42 \\
\hline
\end{tabular}




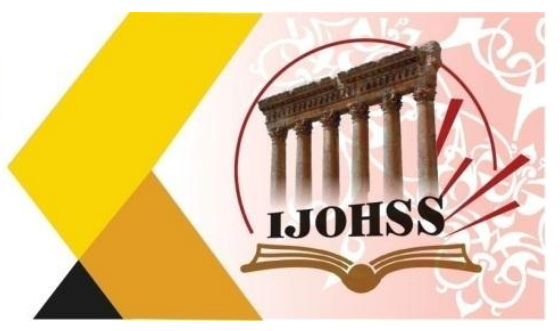

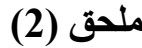

اسنبانة الاختبار بصيغته النهائية (جائحة كورونا واثرها النفسي على معلمة رياض الاطفال)

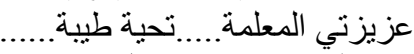

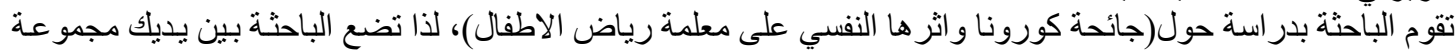

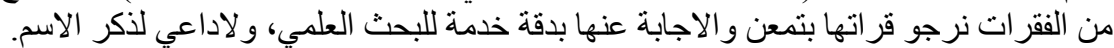

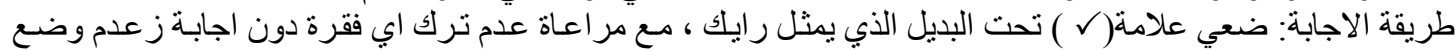
علامنين تحت البديل الو احد.

\begin{tabular}{|c|c|c|c|}
\hline كلا & نعم & 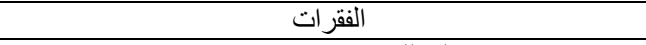 & 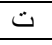 \\
\hline & $\checkmark$ & اجد صعوبة في دخولي للنو بعذ مثاهنتى لاخبار فيروس كورونا & 1 \\
\hline
\end{tabular}
\begin{tabular}{|c|c|c|r|}
\hline & & \\
\hline
\end{tabular}

\begin{tabular}{|c|c|c|c|}
\hline كلا & نعم & الفقرة & 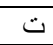 \\
\hline & & اصبحت ابتعد عن الناس وابقى في المنزل بعد انتثار فيروس كورونا & .1 \\
\hline & & لا لا هتم بمعرفة و نسبة الوفيات او المتعافين من الفيروس & .2 \\
\hline & & للا اثترك في المناقثات حول فيروس كورونا او اي موضوع اخر مع زميلاتي & .3 \\
\hline & & اعتقد ان هذا الفيروس هو مكافأ لنا لكي نعيش بمعزل عن العالم المريض & .4 \\
\hline & & افضل التطليم الالكتورني بدلا من ذهابي لللروضة لتنفادي الاصابة بالمرض & .5 \\
\hline & & اشعر بالغثيان عندما تفكر احدى صديقاتي بزيارتي في ظل انتشار المرض & .6 \\
\hline & & اتصنع المرض عندما يطلب مني الذَهاب الى الروضة ( العمل) & .7 \\
\hline & & امتنع عن الخروج من منزلي عندما اعلم ان الفيروس يقترب من مكان اقامتي & .8 \\
\hline & & عند وفاة احد من زميلاتي او احد من اقاربي لااقدم واجب العز اء خوفا من الاصابة بالعدوى و المرض & .9 \\
\hline & & اخاف بشدة على صحتي وصحة اسرتي من هذا الفيروس & .10 \\
\hline & & لا لا اصافح اي شخص خوفا من الاصابة بالمرض و العدوى & .11 \\
\hline & & ليس لدي الطاقة للذهاب الى العمل مرة اخرى في ظل معدلات انتثار الفيروس & .12 \\
\hline & & المعلومات المقدمة عبر وسائل الاعلام العالمبة والمحلية عن فيروس كورونا كاذبة & .13 \\
\hline & & اتعجب من ممارسة الناس لحياتهم بشكل طييعي بالر غم من تصاعد معدلات الوفيات في العالم & .14 \\
\hline & & تقافة المجتمع لاتدربنا على كيفية التعامل مع الاوبئة & .15 \\
\hline & & وسائل الاعلام لاتساهم في نشر الوعي بخطورة هذا الفيروس بين افراد المجتمع & .16 \\
\hline & & يز عجني متابعة اخبار فيروس كورونا في العالم & .17 \\
\hline & & للايوجد اهتمام من قبل وزارة التربية بتو عية الكو ادر النتريسة لكيفية الوقاية من الفيروس & .18 \\
\hline & & اعتقد ان اهدافي في الحياة غبر جديرة بالتفعيل & .19 \\
\hline & & احس ان مناعثي النفسبة لمو أجهة فيروس كورونا اصبحت ضعيفة & .20 \\
\hline & & لم لمتد لدي ابي رغبة بالعمل خوفا من الاصابة بالفيروس & .21 \\
\hline & & لم بعدة هناك شي يدخل السرور على قلبي & .22 \\
\hline & & اشعر ان كل ماتعلمته خلال مسيرتي التُعليمية لايفيدني في كيفية انقاذ نفسي من فيروس كورونا & .23 \\
\hline & & عندما تصاب احدى زميلاتي في العمل اشعر انني لم اقم بدروي نحو ها لانقاذها من الفيروس & .24 \\
\hline & & يجب تعقيم الروضة لاني اشعر ان الفيروس منتشر فيها & .25 \\
\hline & & اقوم بتعقيم مكان جلوسي في الروضة لاكثر من مرة & .26 \\
\hline & & اغسل يدي عشر ات المرات واعقمها للوقاية من الفيروس & .27 \\
\hline & & اشعر ان هذا الفيروس سيصاب به الجميع وقد يؤدي الى موتهم فلماذا نذهب للعمل & .28 \\
\hline & & الافكار والهلاوس تطاردني ليلا عن مصبر من مات جراء هذا الفيروس & .29 \\
\hline & & اخاف ان اغمض عيني حتى لا اسمع خبار موت احدى زميلاتي في العمل & .30 \\
\hline & & اشعر بالانهاك الثديد نتيجة تفكيري طو ال الليل بما سمتنه فيروس كورونا & .31 \\
\hline & & اجد صعوبة في دخولي للنوم بعد مشاهدتي لاخبار فيروس كورونا & .32 \\
\hline & & نومي متقطع بسبب كثرة تفكيري في احتمالية اصابتي بفيروس كورونا & .33 \\
\hline & & اركز قبل النوم في عدد الوفيات اكثر من عدد المتعافين من الفيروس & .34 \\
\hline & & ليس لدي اي رغبة في الطعام خاصة بعد سماعي اخبار انتشار فيروس كورونا & .35 \\
\hline & & الطعام متعه و علينا الاستمتاع به قبل نهاية العالم & .36 \\
\hline & & اششر ان وزني زاد بعد انتشار فيروس كورونا & .37 \\
\hline & & اصبح استهلاكي للمو اد الغذائية قد ازداد الى الضعف عما كان عليه قبل انتثار فيروس كورونا & .38 \\
\hline & & اشغل نفسي بصنع العديد من الاكلات هروبا من سماع الاخبار عن فيروس كورونا & .39 \\
\hline
\end{tabular}

